\title{
CURRENT MONGOLIAN CULTURAL PROBLEMS: INTERNAL AND EXTERNAL
}

\section{Mashbat O.Sarlagtay (Mongolia)}

Philosophy is universal, but the main problems of current philosophy are always different from one region to another. The main problem of Hellenic or ancient Greek philosophy was the source of the universe: material or intellect. Because their question was the source of the universe, they easily accepted Christianity. However, in Eastern philosophy, matter was the status of man in the universal world, including Heaven and Hell.

The basic problem of ancient Mongolian philosophy, caused by Mongolia's nomadic lifestyle, was how to adopt into the natural environment and how to organize people to survive through natural harshness '. Because of that, the first, Mongolians became the most opportunistic people in the world, and their ability to adapt is amazing. Second, the political heritage of Mongolian statehood has had a rich and distinguished adaptive experience. Mongolian culture and customs became very specific.

Mongolian Khans ruled their people two ways: one by "rule by moral force" and other by "rule by law". Chingis Khan successfully used those two ways. He delivered the "Great Yasa," implementing the rule of law and "Bileg Surgaali," a book introducing moral principles. The "Great Yasa" is very familiar in foreign countries that were under the rule of the Great Empire. "Bileg Surgaali" became the book that one who is willing to become an intelligent man traditionally had to study at first; it is still popular among Mongolian Diaspora today.

There is a supporting idea of this tradition in modern state theory. Modern state theory cites that state power has two aspects, authority and legitimacy ${ }^{2}$. Authority of the state requires an understanding of legal enforcement. But legitimacy of state power relies on the belief of citizens in the current state and usually is provided by the national ideology or what we call "nationalism".

During the Communist era, Mongolian state ideology was MarxismLeninism and proletarian solidarity. However, traditional pride of Mongolians was suppressed; most of population really believed in establishing paradise on earth for the poor and slaves, and their moral value became Communist. Mongo-

${ }^{1}$ D.Dashpurev. "Etapi Modernizatsii Mongoliskogo Obszestva (ModernizationStages of the Mongolian society)” on Russian. UlanBator. 1995, PP 43-44.

2 Donald M.Snow. "National Interesf'. N.Y. 1987 p7 
lians were proud of their social lower-class origins, worker class status and even poor living conditions.

The ideology was so strong that people destroyed Buddhist temples, key to their traditional religion, executed thousands of lamas and abandoned much of traditional statehood heritage. More than 90000 people, from high officials to ordinary herders and lamas, were executed in the repression during 1930's. Indeed, it was $20 \%$ of the adult population comparing to 700 thousands of whole population of the days ${ }^{3}$. Mr. Elbegdorj, one of the democratic leaders, has mentioned in his briefing in 1993 that the one sixth of whole population of Mongolia had been executed during the communist regime ${ }^{4}$. From 900 of monasteries those existed before ${ }^{5}$ the people's revolution, only one has remained and practiced under the strict control of the MPRP, during the communist regime.

Later, in place of such cruel bloody acts, Mongolia introduced Western culture and joined the global world ${ }^{6}$. At the very beginning of the revolution, people's government introduced modern but socialist type of financial and commercial services, industry and transportation based on state property with soviet aid and the worker class, a completely new social phenomenon of the days, was born. In the result of this development it had been laid down the roots of the light industry. Leaders of the government have concluded in 1961 that Mongolia has stepped to agricultural-industrial country from agricultural. The XV party congress held in 1961 has adopted the $4^{\text {th }}$ program of the MPRP, and stated that "The main economic challenge of this stage is completion of laying down material and technical base of socialism in the most effective way such as industrialization, mechanization of the agriculture, improvement of technical supply of every branches of people's economy. In the near term, the party goals to change the People's Republic of Mongolia to industrial and agricultural country which economic structure has balanced between main branches of socialist economy, including raw materials and final product industries."’

${ }^{3}$ D.Dashpurev. "Etapi Modernizatsii Mongoliskogo Obszestva (ModernizationStages of the Mongolian society)" on Russian. Ulaanbaatar. 1995, PP 101-102.

${ }^{4}$ Ts. Elbegdorj. "Mongolia who found its identities". Briefing in the ceremony of "Young Leader" foundation, after his receiving of honor "the young politician of the year 1992". Ulaanbaatar. 1993.

${ }^{5}$ D.Dashpurev. "Etapi Modernizatsii Mongoliskogo Obszestva (ModernizationStages of the Mongolian society)" on Russian. Ulaanbaatar. 1995, p 103.

${ }^{6}$ S.Soyombobaatar. "Onuugiin Mongoliin niigem dehi unet zuiliin zarim asuudal" (Some axiological problems of current Mongolian society). Diploma thesis. NUM. 1997. pp. 14-15.

${ }^{7}$ B.Shirendev." Kapitalizmiig algassan in (Jump over capitalism)". Ulaanbaatar. 1968, pl27 
One of the main parts of the goal was justification of Mongolians. The report of Yu.Tsedenbal on the second Plenary session of the Central Committee of the MPRP, held in 1972, pushed idea of that every Mongolian must speak Russian. In 1979, it was launched "wide use of progressive soviet experiences to establish socialism in Mongolia completely", indeed, it was justification policy under logo of "socialist lifestyle". According to these acts all high educational establishments taught on Russian, and Soviet Union became an example of highest development, a dream of Mongolians. Imitation of Russians began to spread all over society, and in fact Mongolia became the sixteenth republic of Soviet Union in terms of culture. Mentality of imitation is still kept in the mind of the mass.

The goal of laying down material and technical base of socialism had been continued until collapse of communist regime in Mongolia. In late of 1980's, economy began to exhaust its resources, living condition began to diminish, and it became visible that communism has no future. Besides, governors were refused to follow the Soviet's perestroika in terms of politics, and people were in shock because of sudden refusal of their previous imitating habits of Russians.

The Democratic Revolution in the 1990's led to not only to a change of political and economic systems, but also intellectual change. The end of the Cold War and fall of the Communist regime gave Mongolians private property, the right to feed themselves, political freedom, and the right to choose those who govern. However, democracy didn't tell people how to behave.

In the beginning, the change in the social system caused a sudden rise in national feeling, which had been suppressed in the past. The people, who had been drawn away from tradition and grew up without almost any knowledge of tradition, emotionally began to imitate their ancestors, even inventing primitive traditions without consciousness and hate all heritages from Communism, including the positive and global ones. Elder generation, imitating old Mongolians, began to have long hair, to wear long red deel (traditional mongolian cloth). But they unconsciousness changed or reinvented old Mongolian restriction of drinking alcohol during traditional feast of New Year.

Simultaneously, calling them "hoary nationalists" those with opposite opinions arose and began to dispute that nomadic people usually live in primitive habits and don't have any cultural heritage. They, the modernists, ignored not only all Mongolian traditions, but also Eastern civilization and assumed it had barbarian habits. They created "the union of protection of Damdinsuren's

${ }^{8}$ D.Dashpurev. "Etapi Modernizatsii Mongoliskogo Obszestva (ModernizationStages of the Mongolian society)” on Russian. Ulaanbaatar. 1995, pp. 146-151. 
script" or Mongolian version of Russian Cyrillic's, protesting nationalist attempt of declaring thousand years old traditional Mongolian script as an official script of Mongolia. Modernist also ignored Chingis Khan's role in the history, judging him as an aggressor, killer and violent barbarian leader.

Today it seems that "hoary nationalism" was an attempt of unconsciousness imitating of ancestors, while modernist ideology was an inertia of satellite mentality that saw the Mongolian history and culture from Russian point of view 9 . Both of those extreme opinions had their positives. Nationalists tried to reanimate all traditions, most of which are positive, including traditional script and statehood philosophy. Their opposition tried to maintain all successes that were earned during the Communist period, worrying those nationalists could destroy them.

With the market economy and liberal ideology of newly born private entrepreneurs, or "novae riche," and small business owners, a cosmopolitan ideology gained and nationalism began to diminish. Democracy and economic liberalization has significantly promoted spread of liberal cosmopolitanism Besides the ideology of emerging entrepreneurs, two main factors are playing the most important role in wide spread of liberal cosmopolitanism. They are; urbanization and demographic specifics of Mongolia.

Currently, Mongolian society composed from two different cultures: nomadic and urban ${ }^{10}$. More than two third of the population is settled in urban area $^{11}$. but animal husbandry is still strong in its economic structure. Government policy to develop industry, in order to provide solid base for economic growth, was directly influenced in increasing of urban population and meantime it drove to emergence of new lifestyle, the urban one. For 70 years of communist regime, diversity between urban and rural population has not been widened because of centralized planning economy, but for last decades, the diversity is

${ }^{9}$ I.V.Orlova. "Evraziiskaya Tsivilizatsiya (Eurasian Civilization)”. Moscow, 1998, p 55. I.V.Orlova critiques organist way of explanation of Russian history and corresponding conclusions about Mongolian rule over Russia. No nations, but Russians always blame Mongolian rule for its violence and brutality, which is not much credible, while nations like China and others of Middle and East Asia, those were also under Mongolian rule, see the matter in different way. Mormonism of Russian history is dedicated to show that Russia belongs to European civilization; therefore, it proves that origin of Russian statehood derived from Scandinavia, but Mongolians had drawn Russians away from their European core of civilization and blames for it.

${ }^{10}$ Alicia J.Campi. "Moving Mongolian nomadism into the 21 century: Cultural and ecological preservation coupled with economic vitality and national security". Research thesis. Washington. 1997.p7

${ }^{11}$ Human development report Mongolia 1997". UlanBator. 1997. p 3 
quickly widened in terms of social benefits, business opportunities, living standards and especially, cultural mentalities. ${ }^{12}$

Urban lifestyle has been emerged under Soviet and East European influence. That is why Mongolian urban population determines that they have more European lifestyle than Asian. For last decade, the urban mentality was affected by strong oriental cultural influences, including Korean, Japanese and Chinese. Composition of urban population has also a significant portion of immigrants, recently settled from rural areas. With these reasons, current Mongolian urban mentality is very complicated. In spite of these facts native urban citizens, whose pioneers were under East European influences, maintain their majority in both terms of composition and mentality. It has also promoted to spread of liberal cosmopolitanism.

Also demographic factors play the important role in wide spreading of liberal cosmopolitanism. Mongolia is one of the world's youthful countries. Over $70 \%$ of the population is under age of 35 and $45 \%$ is children under age of $15^{13}$. It is in youth culture that changes are most pronounced. There is a funny phenomenon in politics that political parties are usually facing difficulties to nominee candidate in presidential election, who must be not younger than 45 years old. Even 70 years old MPRP faces the same problem finding a person who does not have a communist image and is eligible in fixed age by the constitution. In effect of global information flow, especially urban young generation, called MTV generation, began to be driven from traditional nomadic values away.

Excessive liberal cosmopolitanism is the current face of Mongolia. It has had negative results in Mongolian society today, which diminish national feeling and ignore patriotism among the population. If rising liberalism might be example of the opportunistic and adaptive ability of Mongolians, but it is harmful for Mongolia's existence as a nation

Current Mongolian society is imitating America, and political leaders are encouraging it. For young generation, America is a perfect example of high development, which was Soviet Union for their parents (see above). Imitation of someone, rather than to be in yourself, is the consequence of diminishing patriotic nationalism and inertia of satellite mentality.

It is obvious that there is an absence of government regulations or what called "rule by morality." Fear from state ideology, caused by Communism, makes

${ }^{12}$ Alicia J.Campi. "Moving Mongolian nomadism into the 21 st century: Cultural and ecological preservation coupled with economic vitality and national security". Research thesis. Washington. 1997. pp. 7-9.

${ }^{13}$ Mongolian economy; yesterday, today and tomorrow" UlanBator. 1999. p 15. 
leaders unable to deal with this kind of matter. If the Mongolian Government will not deal with this problem further, state authority will lose its legitimacy and national security will face threats.

Culturally, Mongolia is a unique country. Samuel Huntington, author of the book "The Clash of Civilization" and one of founders of the theory of civilization, has classified Mongolia to Buddhist civilization ${ }^{14}$, remarking its Lamaist variant of Mahayana Buddhism. But he has completely ignored Mongolian nomadic lifestyle.

Mongolia used to belong to the "East European countries plus Mongolia" camp, as we call. It was not only because of its Soviet-oriented political regime and close socio-political ties with European socialist countries, but also in terms of "new socialist lifestyle", one of the communist Utopias. But after the fall of the Communist block, it faced the problem of re-determining its position in terms of culture and civilization.

Eastern European countries had had the experience of capitalism and common culture based on Christianity; for them, Communism was a terrible thing that could destroy society, but they were forced to accept it. However, for Mongolians, Communism was not only an opportunity to reestablish their independence, but also a bridge to reach a common cultural heritage. Mongolia accepted Communism by force too, but perceived it as payment for modernization. Former socialist European countries always were part of Western Civilization, and western influences essentially contributed to their transition not only in political and economic fields, but also to intellectual ones. In contrast, Mongolia is almost in a helpless situation between Russia, where social uncertainty is still continuing, and China, where the Communist regime is still stabile.

Mongolia is located on the junction of three main civilization areas represented by the three major religions, Christianity (Northern neighbor), Confucianism (Southern neighbor), and Islam (Kazakhstan is a culturally direct bordering neighbor; also Mongolia has Kazakh Diaspora), but is itself a Buddhist country. Even Mongolian Lamaism derived from Tibet and has its origins in Mahayana Buddhism, different from the Hinayana Buddhism that spread in Myanmar, Thailand, Cambodia and other Asian countries.

Mongolia has a nomadic culture, but comparing to other nomadic people such as Kazakhstan and Kyrgyzstan, it also has Buddhism.

Mongolia doesn't accept Chinese culture. Traditionally, Mongolia was in the "Inner Asian Zone" in terms of Chinese security ${ }^{15}$. Thus obviously it has had some influences, but not much. Taoism and Confucianism were not popular;

\footnotetext{
${ }^{14}$ Samuel P.Huntington., "The Clash of Civilization" N.Y.1987. p,48

${ }^{15}$ Samuel P.Huntington. "The Clash of Civilization" N. Y. 1987. p 168
} 
there was no soil to grow their seeds, because of different lifestyle. Mongolian cultural heritage, especially for the last three centuries, was similar to Tibetan, but Tibet is now under the authority of the PRC. There are certain possibilities to use Lamaism with purpose of creating Dalai Lama's institution in Mongolia, which is not desirable for us.

Some researchers from former soviet countries launched an idea of "Eurasian culture and civilization", remarking the Mongolian contribution to establish it. Great Empire of Mongolia was the third Eurasian Empire in the edge of second millennium and had played significant role in forming new states in wild steppe of Eurasia ${ }^{16}$ for next millennium. From Lithuania to Kyrgyzstan it had great influence and countries those arisen after the Mongolian Empire, including Russians, inherited Mongolian statehood philosophy.

One of the problems that face Mongolia is the absence of active political and economic integration in its vicinity. In the North, Russia is still in crisis and exhibits no positive sign of standing on its feet in the near future. In the West, the situation in Kazakhstan is almost the same as in Russia. China, our Southern neighbor, has a very high growth of economic development but it still has a strong Communist regime, and there are certain possibilities of conflict in its political regime and economic system. In the East, there is a divided Korea, "the last piece of ice of the Cold War." Thanks to the two Korean leaders, their recent acts bring us hope that the ice is beginning to melt.

In conclusion, since the end of the Cold War, Mongolia is facing a problem of national ideology and identity in internal affairs and is seeking integration not only in political and economic fields, but also culturally, in external environments. There is no way to live alone or outside of global integration. Mongolia has to develop a conservative state ideology to maintain its national identity and an active policy to join an Asian and global world.

The camp of "East Europeans, plus Mongolia" is a matter of past. Mongolia has to determine itself as an Asian country on both geographical and cultural bases. In so doing, Mongolia is seeking to join ASEAN, which is an Asian type of integration model. Also Mongolia strives to contribute to the Tumen River economic free zone project and join to the pipeline project from Siberia to Japan, hoping to lay the base of Northeast Asian integration. Unfortunately, political power to make decision is not under authority of Mongolia, but major powers in Northeast Asia.

In the early 1990's Mongolia was "an island of democracy in the heart of a continent” surrounded by the USSR and PRC. Now, Mongolia doesn't want to remain an isolated island in the heart of a continent surrounded by globalization.

${ }^{16}$ I.B.Orlova. "Evraziiskaya tsivilizatsiya”( Eurasian Civilization), Moscow, 1998. p 107. 